\title{
ARSENIC REMOVAL FROM WATER USING A NEW CLASS OF MATERIALS WITH ADSORBENT PROPERTIES
}

\author{
MIHAELA CIOPEC ${ }^{1}$, IOSIF HULKA ${ }^{2}$, NARCIS DUTEANU ${ }^{1}$, ADINA NEGREA ${ }^{1}$, OANA GRAD ${ }^{2}$, \\ PETRU NEGREA $^{1}$, VASILE MINZATU ${ }^{1} \&$ CRISTINA ARDEAN ${ }^{1}$ \\ ${ }^{1}$ Politehnica University Timisoara, Faculty of Industrial Chemistry and Environmental Engineering, Romania \\ ${ }^{2}$ Research Institute of Renewable Energy of Politehnica University Timisoara, Romania
}

\begin{abstract}
One of the strategies for sustainable development is to promote a quality health care system, available to all without discrimination, and improving protection against health threats. In this context, arsenic removal from groundwater for drinking purposes presents challenges at national and global levels. Thus, the present article focuses on removing arsenic from groundwaters by using a new class of materials based on cellulose modified with crown ether (dibenzo-18-crown-6) doped with iron ions. Using such extractants involves only a small amount of crown ether, indicating higher efficiency of produced material, and in order to improve the adsorbent properties and selectivity for arsenic removal, the modified cellulose was functionalized with iron ions.

The new adsorbent material was characterized by using energy-dispersive $\mathrm{X}$-ray analysis and Fourier-transform infrared spectroscopy. To investigate its adsorption properties for arsenic removal, equilibrium, kinetic and thermodynamic studies were performed. Arsenic adsorption from water onto new class of adsorbent material was studied under different experimental conditions such as reaction time, initial arsenic concentration and temperature. Kinetic of adsorption process was better described by pseudo-second-order model. The equilibrium adsorption data were well described by the Sips adsorption isotherm. The values of thermodynamic parameters $\left(\Delta \mathrm{G}^{\circ}, \Delta \mathrm{H}^{\circ}, \Delta \mathrm{S}^{\circ}\right)$ showed that the adsorption process was endothermic and spontaneous.

The possibility of reuse of the adsorbent material through adsorption and desorption cycles was also studied, and it was found that the material can be used in three adsorption-desorption cycles.

Keywords: crown ethers, arsenic, adsorption, iron ions, water.
\end{abstract}

\section{INTRODUCTION}

Arsenic removal from water is an important and urgent preoccupation and, in this sense, nowadays a series of techniques for arsenic removal are studied and developed. Arsenic is the 20th element and it is found in groundwaters, which became a major problem for the world due to its toxicity especially for countries like Bangladesh, India, China and Japan [1,2]. Bangladesh and provinces adjacent to India such as Bengal are the most affected regions of the world, in which the drinking water of more than 100 million people was contaminated with arsenic and $21 \%$ of deaths were reported because of arsenic poisoning [3-6]. Many industries release arsenic without adequate treatment of the water sources. In various regions, the anthropic source was registered as a major source for a higher concentration of arsenic in groundwater [1], and the arsenic content in drinking water over maximum admitted level by the World Health Organization (10 $\mu \mathrm{g}$ As L-1) has a negative impact on human health [4-8]. For this reason, arsenic removal from water is an important and urgent preoccupation, and in this way a series of techniques for removing arsenic have been developed. These include precipitation-filtration processes [9]; coagulation-precipitation processes [10], chemical oxidation, oxidation-coagulation or oxidation-precipitation [11]; electrocoagulation [12]; membrane separation such as nanofiltration, reverse osmosis, electrodialysis [13-15], ion exchange [16] and adsorption [17-22]. 
Among arsenic removal procedures, adsorption is a process with a good efficiency, but an important role is played by the adsorbent material used into the process. Thus, it is very important to develop new methods to produce adsorbent materials with weight adsorption capacity by chemical modification of inorganic and organic solid supports, through functionalization with different pendant groups. Natural polymers as adsorbent materials for arsenic removal from water present a special attention [23-25]. From environmental point of view, the most common and most cost-effective biopolymer available from natural sources is cellulose [26]. Cellulose has proved to be an excellent example in terms of versatility for surface modification [27-29]. Modifying the cellulose structure with crown ethers might be a new method successfully used for metal ion removal from water due to crown ether properties which allow the complexation and embedding of metallic ions inside their structure or at their surface [30]. Researches performed during the last decade proved that the iron ions increase the affinity of adsorbent materials towards arsenic ions.

Based on that, the goals of this article were to obtain a new material with improved adsorbent properties by functionalization cellulose using crown ethers as extractants, followed by loading with iron. The article consists in extended studies of our previous work [31] regarding the chemical modification of cellulose through functionalization with crown ethers and loaded with iron ions for arsenic adsorption from waters. The physical-chemical modification of cellulose by functionalization with dibenzo-18-crown- 6 and loaded with $\mathrm{Fe}$ (III) ions represent a good choice for $\mathrm{As}(\mathrm{V})$ removal from aqueous solutions, due to the fact that cellulose is a relatively inexpensive support and the amount of crown ether necessary for the functionalization is very small, but with representative effect for the adsorption process.

\section{MATERIALS AND METHODS}

In order to obtain the new class of adsorbent material by chemical modification of solid support, the following were used: as support - cellulose (AVICEL 101, microcrystalline, powder, Sigma-Aldrich, Merck) with a particle size of $\sim 50 \mu \mathrm{m}$, as extractant - dibenzo-18-crown-6 (DB18C6) (purity, 98\%, Sigma-Aldrich, Merck, Germany) and iron chloride as iron sources purchased from Sigma-Aldrich.

\subsection{Functionalization of polymer}

To obtain the adsorbent material, $0.05 \mathrm{~g}$ of dibenzo-18-crown-6 (DB18C6) was accurately weighed and dissolved in $25 \mathrm{~mL}$ nitrobenzene (Sigma-Aldrich, Merck, analytical standard). The obtained extractant solution is added over $5 \mathrm{~g}$ of support cellulose with a particle size of $\sim 50 \mu \mathrm{m}$. The Solvent Impregnated Resins (SIR) dry method was used to functionalize the support. The functionalization is presented schematically in Fig. 1. Thus, the extractant and the support remain in contact for $24 \mathrm{~h}$, after which it is filtered and dried in oven at $50^{\circ} \mathrm{C}$ for $24 \mathrm{~h}$.

To load the material with iron ions $25 \mathrm{~mL}$ of $\mathrm{FeCl}_{3}$ solution with concentration of $100 \mathrm{mg}$ $\mathrm{L}^{-1}$ was added, left in contact for 24 hours, then filtered and dried in the oven for $24 \mathrm{~h}$.

\subsection{Characterization of the functionalized polymer}

The obtained material was characterized by X-ray energy-dispersive spectroscopy (EDX) using a FEI Quanta FEG 250 Scanning Electron Microscope and Fourier-transform infrared spectroscopy (FTIR) using a Bruker Platinum ATR-QL Diamond instrument in the range of $4,000-400 \mathrm{~cm}^{-1}$. 


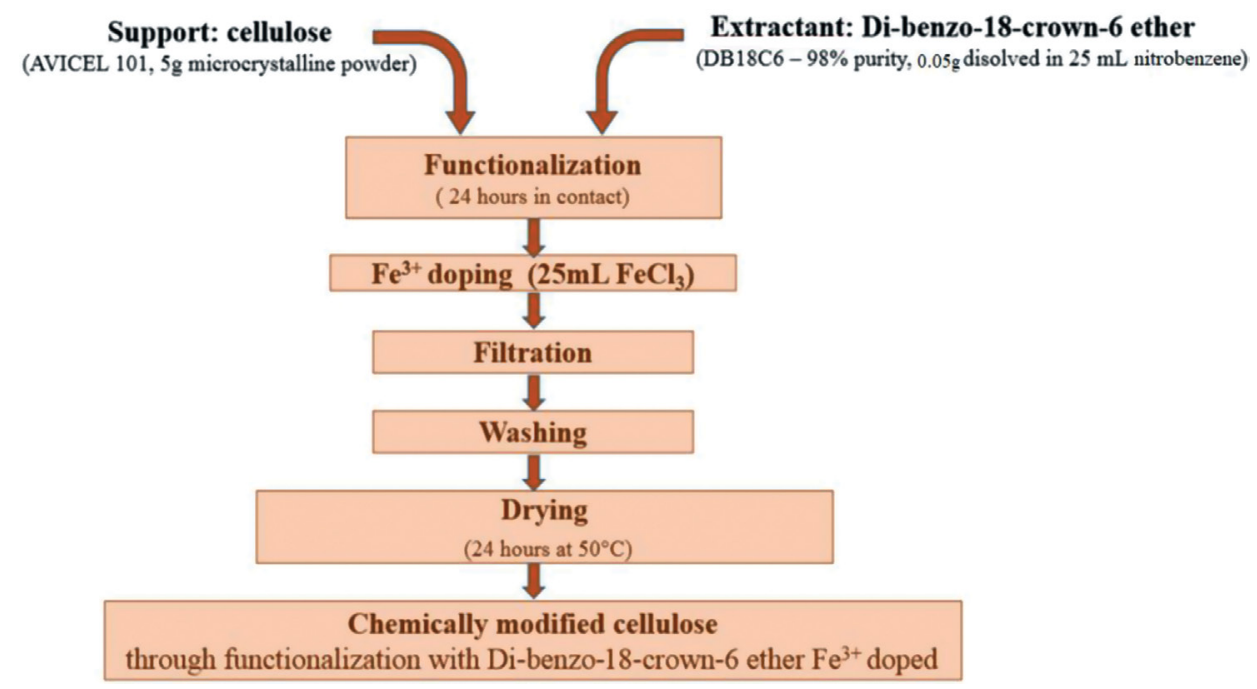

Figure 1: The principle steps for functionalization of the solid support.

\subsection{Sorption studies}

In order to determine the optimum conditions for the arsenic adsorption process, experiments regarding contact time, initial concentration of $\mathrm{As}(\mathrm{V})$ and temperature were carried out. Therefore, a Julabo SW23 thermostatic and shaking water bath with a stirring speed of $200 \mathrm{rpm}$ was used.

To establish the influence of contact time and temperature on the adsorption capacity of the adsorbent material, $0.1 \mathrm{~g}$ of material was mixed with $25 \mathrm{~mL} \mathrm{As}(\mathrm{V})$ solution with concentration of $50 \mu \mathrm{g} \mathrm{L}^{-1}$. Samples were shaken for different time periods $(0.5,1,2,3,4,5,6$, 7 and $8 \mathrm{~h}$ ) in a thermostatic bath at different temperatures $(298 \mathrm{~K}, 308 \mathrm{~K}$ and $318 \mathrm{~K})$ with a stirring speed of $200 \mathrm{rpm}$. Afterwards, all samples were filtered and the filtrate was analysed in order to evaluate the arsenic residual concentration using an inductively coupled plasma mass spectrometer ICP-MS Bruker Aurora M90. In order to establish the effect of the initial concentration of $\mathrm{As}(\mathrm{V})$ on the adsorption capacity of materials, different concentrations of As(V) solutions (10, 25, 50, 75, 100, 150, 175 and $\left.200 \mu \mathrm{g} \mathrm{L}^{-1}\right)$ were prepared. Adsorption processes were carried out at $\mathrm{pH} \sim 7$, for a contact time of $4 \mathrm{~h}$ at $298 \mathrm{~K}$.

\section{RESULTS AND DISCUSSION}

\subsection{Characterization of the materials}

\subsubsection{X-ray energy-dispersive spectroscopy}

Cellulose functionalized with DB18C6 and loaded with iron ions was characterized by using X-ray EDX technique. The obtained data are presented in Fig. 2.

From the EDX spectra and quantification, the presence of specific peaks ascribed to elements found in the chemical structure of cellulose and crown ether, namely $\mathrm{C}$ and $\mathrm{O}$, might be observed as well as iron. 
c

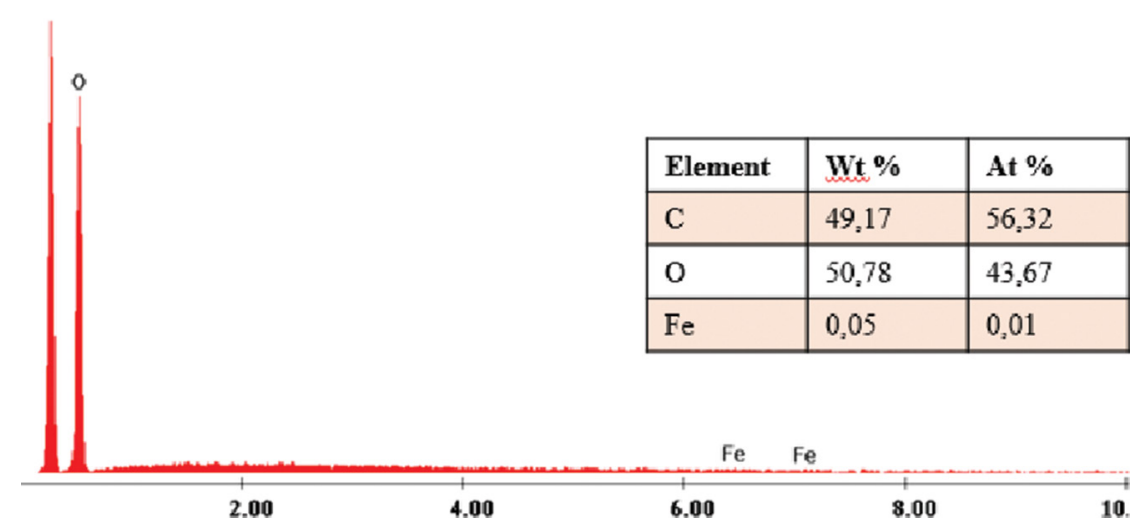

Figure 2: EDX spectra of materials obtained by functionalized cellulose with crown ether DB18C6 and iron ions.

\subsubsection{Fourier-transform infrared spectroscopy}

FTIR spectroscopy is used to identify chemical groups as well for quantitative analysis of the new material. The FTIR spectra for cellulose functionalized with DB18C6 and iron are shown in Fig. 3.

From FTIR spectra, bands specific for cellulose groups were identified in the range of $3,200-3,400 \mathrm{~cm}^{-1}$ associated with the stretching vibrations of O-H bonds [30]. A band located around $1,600 \mathrm{~cm}^{-1}$ was as well identified, and it is characteristic for stretching vibrations of water and specific $\mathrm{O}-\mathrm{H}$ bonds. The bands located at 1,720 and $1,600 \mathrm{~cm}^{-1}$ are assigned to

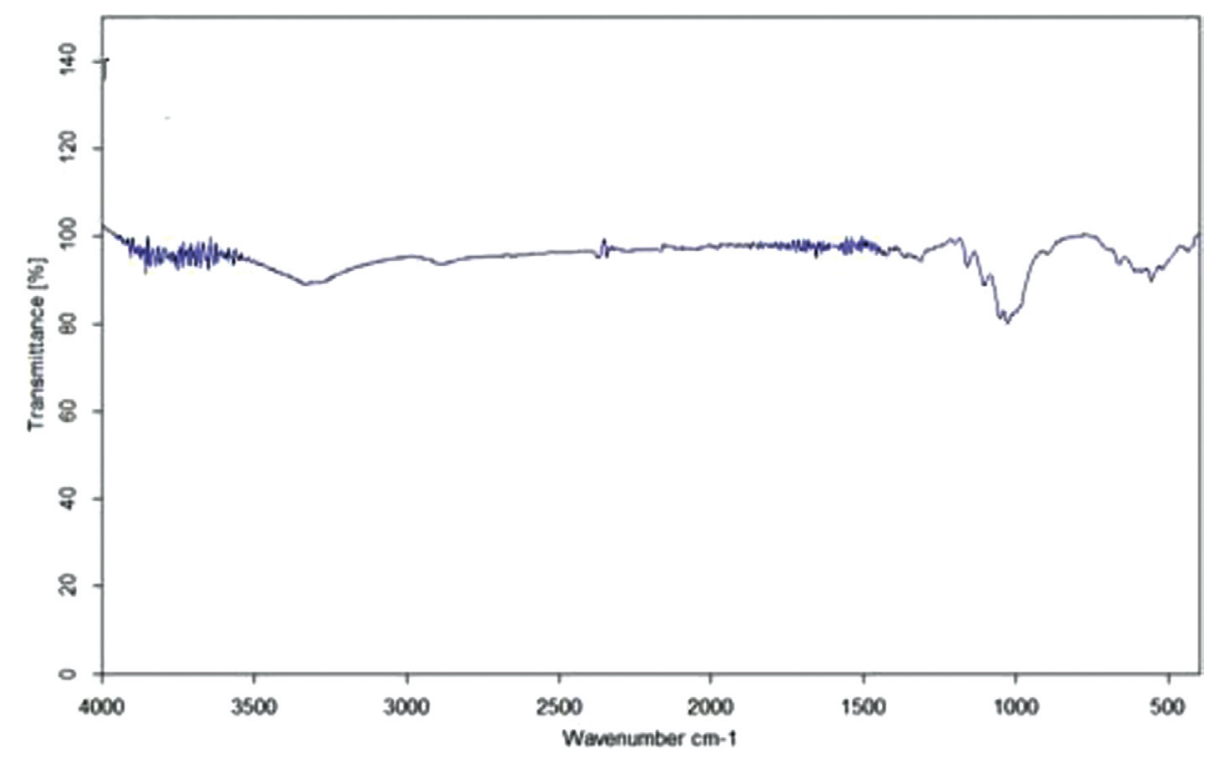

Figure 3: IR spectra of materials obtained by functionalized cellulose with crown ether DB18C6 and iron ions. 
aromatic $\mathrm{C}=\mathrm{C}$ bond stretching vibrations [32]. Bands characteristic of DB18C6 extractant appear in the range $1,550-500 \mathrm{~cm}^{-1}$, the most intense ones are located at $1,000 \mathrm{~cm}^{-1}$ and 550 $\mathrm{cm}^{-1}[33]$.

Thus, dibenzo-18-crown-6-crown ether-specific vibration bands can be observed at around $1,000 \mathrm{~cm}^{-1}$ and $1,100 \mathrm{~cm}^{-1}$, which might be attributed to calphatic-O-caromatic and calphatic$\mathrm{O}$-calphatic bonds, respectively [32]. Iron surface loading is evidenced by the presence of the band located at $1,037 \mathrm{~cm}^{-1}$, which is characteristic for the $\mathrm{Fe}-\mathrm{OH}$ bonds [30].

\subsection{Sorption study results}

3.2.1. The effect of contact time and temperature

The effect of contact time on the adsorption of $\mathrm{As}(\mathrm{V})$ on the functionalized material was studied as it was previously described. The adsorption capacity of the material, $q\left(\mu \mathrm{g} \mathrm{g}^{-1}\right)$, was calculated using the following equation:

$$
q=\frac{\left(\mathrm{C}_{0}-\mathrm{C}_{\mathrm{f}}\right) V}{\mathrm{~m}}
$$

where $C_{\mathrm{o}}$ is the initial concentration of $\mathrm{As}(\mathrm{V})$ from solution $\left(\mu \mathrm{g} \mathrm{L}^{-1}\right), C_{\mathrm{f}}$ is the residual $\mathrm{As}(\mathrm{V})$ concentration from solution $\left(\mu \mathrm{g} \mathrm{L}^{-1}\right), V$ is the volume of solution $(\mathrm{L})$ and $m$ is the mass of the adsorbent material $(\mathrm{g})$.

Obtained experimental data are shown in Fig. 4. For this study, contact time was varied between 0.5 and $8 \mathrm{~h}$, and temperature is in the range of 298-318K. From data depicted in Fig. 4 , it can observed that the adsorption capacity increases with the increase of contact time, and the equilibrium is reached after about $4 \mathrm{~h}$ for all temperatures used during the test.

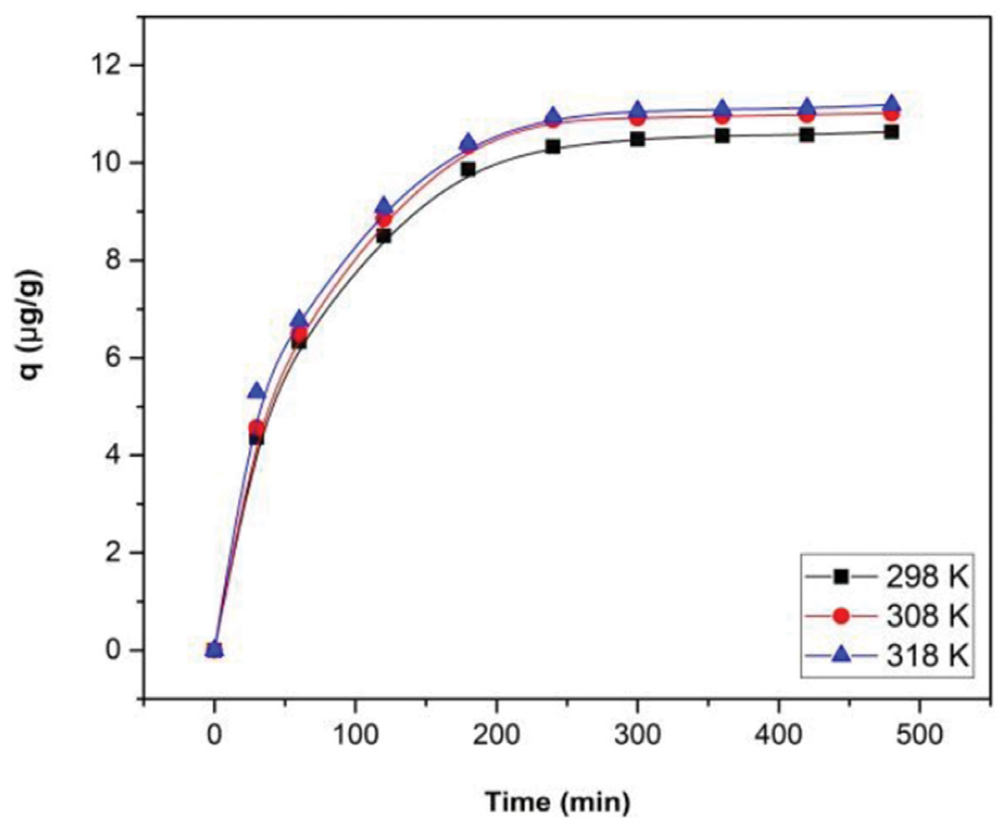

Figure 4: Effect of contact time on the adsorption capacity of the studied material at different temperature. 
It might be observed that with increase in the temperature, the adsorption capacity of the material is not significantly affected.

\subsubsection{Sorption kinetic studies}

The kinetics of the As $(\mathrm{V})$ adsorption process on material has been studied using two kinetic equations that could describe the process: pseudo-first-order kinetic equation proposed by Lagergren and the pseudo-second-order kinetic equation. The pseudo-first-order equation can be expressed as such:

$$
\frac{\mathrm{dq}_{\mathrm{t}}}{\mathrm{dt}}=\mathrm{k}_{1}\left(\mathrm{q}_{\mathrm{e}}-\mathrm{q}_{\mathrm{t}}\right)
$$

where $q_{\mathrm{e}}$ and $q_{\mathrm{t}}$ are the adsorbed amounts of $\mathrm{As}(\mathrm{V})$ per unit mass of material at equilibrium and time $t$, respectively, and $k_{1}$ is the rate constant for pseudo-first-order adsorption. The $q_{\mathrm{t}}$ at different times $t$ can be determined by the following pseudo-first-order kinetic equation after integrating:

$$
\ln \left(q_{e}-q_{t}\right)=\ln q_{e}-k_{1} \mathrm{t}
$$

The pseudo-second-order kinetic model can be expressed by the following equation:

$$
\frac{\mathrm{dq}_{\mathrm{t}}}{\mathrm{dt}}=\mathrm{k}_{2}\left(\mathrm{q}_{\mathrm{e}}-\mathrm{q}_{\mathrm{t}}\right)^{2}
$$

where $k_{2}$ is the rate constant for the pseudo-second-order adsorption.

By linearizing this equation, we obtained:

$$
\frac{\mathrm{t}}{\mathrm{q}_{\mathrm{t}}}=\frac{1}{\mathrm{k}_{2} \mathrm{q}_{\mathrm{e}}^{2}}+\frac{\mathrm{t}}{\mathrm{q}_{\mathrm{e}}}
$$

In Figs. 5 and 6, the pseudo-first-order and pseudo-second-order kinetic model plots obtained at the temperatures used during adsorption experiments $(298,308$ and $318 \mathrm{~K})$ as well the kinetic parameters $k_{1}$ and $k_{2}$ are depicted. For the modelling of experimental data, the linear shapes of the two models are used. The speed constant for the pseudo-first-order model was determined from the linear representation of $\ln \left(q_{\mathrm{e}}-q_{\mathrm{t}}\right)$ over time, and the velocity constant for the pseudo-second-order model was estimated from the linear representation of the $t / q t$ function of time.

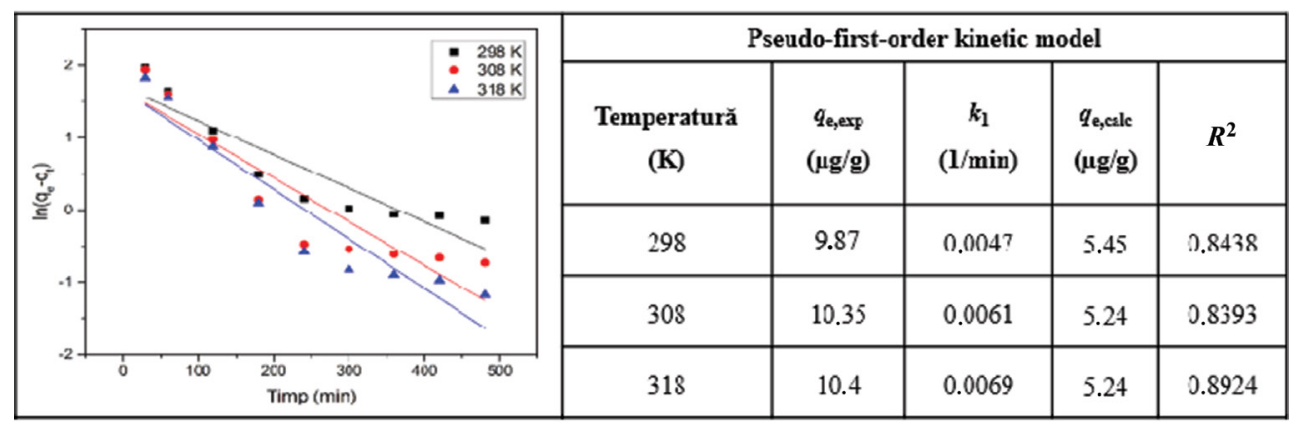

Figure 5: Pseudo-first-order kinetic model and experimental data. 


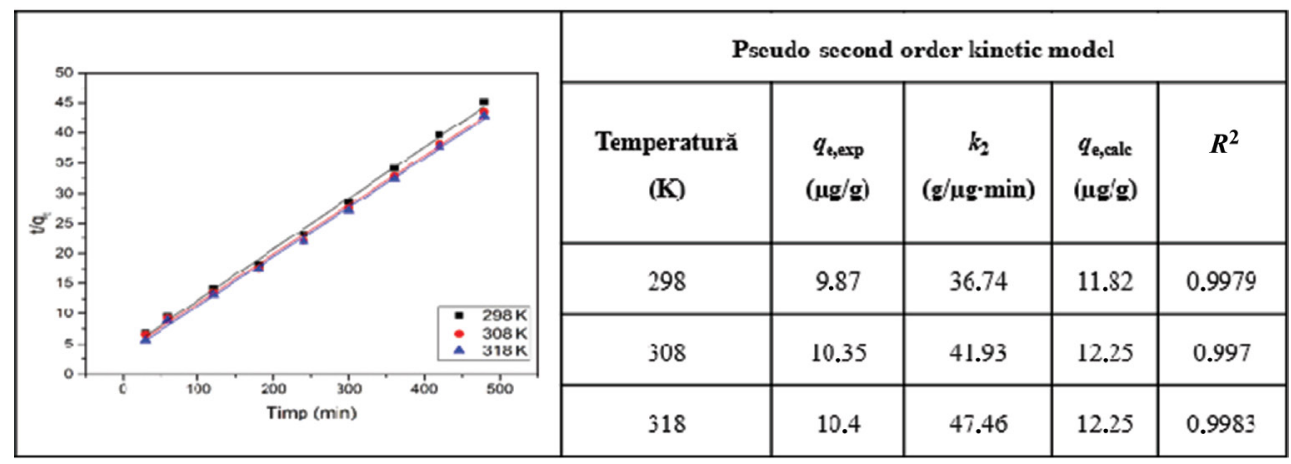

Figure 6: Pseudo-second-order kinetic model and experimental data.

Depending on the obtained values of constants and regression coefficients $\left(R^{2}\right)$, the kinetic model that best describes the adsorption process can be established.

If the correlation coefficient $R^{2}$ is closer to 1 , the adsorption process presents a better linearization for one of the two kinetic models presented. From the experimental data presented in the tables from Figs. 5 and 6, it is observed that pseudo-second-order model is better describing the arsenic adsorption onto the studied material, because the obtained correlation coefficient $R^{2}$ is in the range of $0.9970-0.9983$ depending on the temperature and it is higher than that obtained for the pseudo-first-order model $\left(R^{2}=0.8438-0.8924\right)$. The fact that adsorption kinetics was better described by the pseudo-second-order kinetic model suggested that the $\mathrm{As}(\mathrm{V})$ removal process corresponds to a chemisorption mechanism.

\subsubsection{Sorption equilibrium studies}

In order to establish the $\mathrm{As}(\mathrm{V})$ behaviour on the surface of the adsorbent material during the adsorption process, the experimental data obtained were modelled according to Langmuir, Freundlich and Sips isotherms (depicted in Fig. 7) which are generally used to describe the adsorption processes. Langmuir isotherm is applied for homogeneous surface adsorption

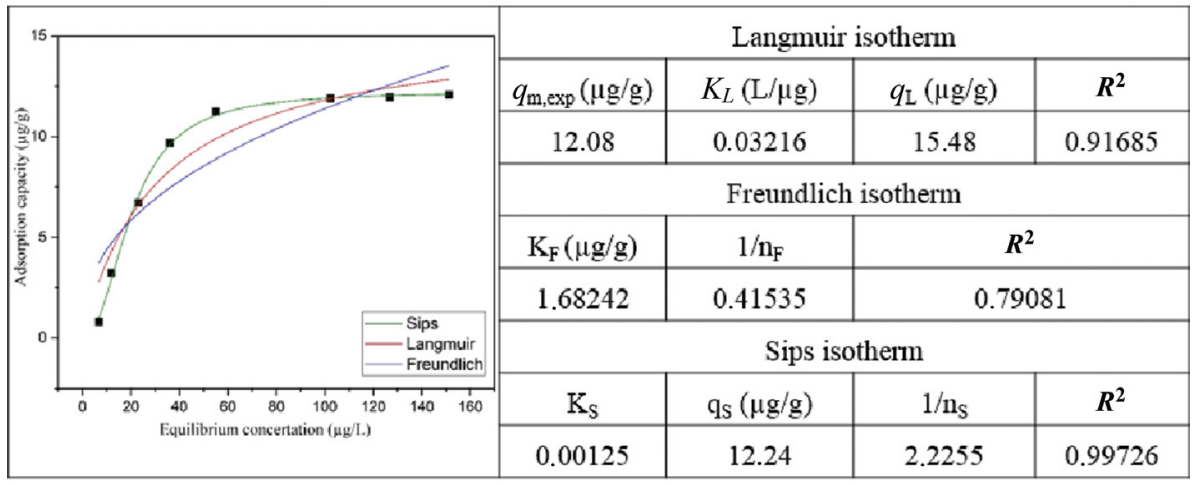

Figure 7: Adsorption isotherm of $\mathrm{As}(\mathrm{V})$ onto material and parameters of isotherm model. 
[34-37]. Nonlinear expression of the Langmuir isothermal equation [39] can be expressed as follows:

$$
\mathrm{q}_{\mathrm{e}}=\frac{q_{\max } \times K_{L} \times C_{f}}{1+K_{L} \times C_{f}}
$$

where $q_{\mathrm{e}}$ is the the maximum absorption capacity $\left(\mu \mathrm{g} \mathrm{\textrm {L } ^ { - 1 }}\right), C_{\mathrm{f}}$ is the equilibrium concentration or final concentration of $\mathrm{As}(\mathrm{V})$ in solution $(\mathrm{mg} / \mathrm{L}), q_{\max }$ is the Langmuir maximum adsorption capacity $\left(\mu \mathrm{g} \mathrm{g}^{-1}\right)$ and $K_{\mathrm{L}}$ is the Langmuir constant. The Freundlich isotherm can be applied for heterogeneous adsorption surfaces [35,38]. Nonlinear form of the Freundlich isotherm equation is:

$$
\mathrm{q}_{\mathrm{e}}=K_{F} C_{\mathrm{f}}^{1 / n_{f}}
$$

where $q_{\mathrm{e}}$ is the the maximum absorption capacity $\left(\mu \mathrm{g} \mathrm{g}^{-1}\right), C_{\mathrm{f}}$ is the equilibrium concentration or final concentration of $\mathrm{As}(\mathrm{V})$ in solution $\left(\mu \mathrm{g} \mathrm{g}^{-1}\right), K_{\mathrm{F}}$ and $n_{\mathrm{f}}$ are the characteristic constants that can be related to the relative adsorption capacity of the adsorbent and the intensity of adsorption. The Sips' isotherm is a combined form of the two previously presented models. Its nonlinear form [39] is the follows:

$$
\mathrm{q}_{\mathrm{e}}=\frac{q_{s} K_{S} C_{\mathrm{f}}^{1 / n_{s}}}{1+K_{S} C_{\mathrm{f}}^{1 / n_{s}}}
$$

where $q_{\mathrm{s}}$ is the maximum absorption capacity $\left(\mu \mathrm{g} \mathrm{g}^{-1}\right), K_{\mathrm{S}}$ is the constant related to the adsorption capacity of the adsorbent and $n_{\mathrm{S}}$ is the heterogeneity factor.

The experimental data were fitted using eqns (6-8) and the studied isothermal parameters are shown in Fig. 7.

The correlation coefficient $R^{2}$ was calculated to establish which adsorption isotherm describes better the adsorption process of $\mathrm{As}(\mathrm{V})$. Figure 7 presents the parameters obtained for each isotherm used in the study. It can be observed that the highest value of the correlation coefficient $R^{2}$ was obtained when the experimental data were modelled using the Sips isotherm $\left(R^{2}=0.99726\right)$. Thus, it can concluded that the Sips model best described the adsorption process. It is also observed that the value of maximum adsorption capacity evaluated based on Sips isotherm model is $12.24 \mu \mathrm{g} \mathrm{As}^{-1}$, much closer to the experimental value of $12.079 \mu \mathrm{g}$ $\mathrm{As} \mathrm{g}^{-1}$. The results indicated an increased adsorption capacity of the new material compared to chelating polymers loaded with $\mathrm{Fe}^{\mathrm{III}}$ [40] or to silica used as solid support impregnated with crown ether and $\mathrm{Fe}^{\mathrm{III}}$ used for the removal of $\mathrm{As}(\mathrm{V})$ from aqueous solutions [41]. Based on the results, it might be concluded that the adsorption process of $\mathrm{As}(\mathrm{V})$ on the obtained material is monolayer adsorption on a heterogeneous surface. The adsorption mechanism is controlled by chemisorption processes as a result of strong chelation between $\mathrm{As}(\mathrm{V})$ and $\mathrm{OH}^{-}$groups or $\mathrm{Fe}$ (III) ions which are present on the surface of functionalized material. The value of the $n_{\mathrm{S}}$ coefficient with a value under $2\left(n_{\mathrm{S}}<2\right)$ confirmed that the adsorption process is produced by the movement of $\mathrm{As}(\mathrm{V})$ ions from the aqueous phase to the material surface.

\subsubsection{Thermodynamics of the adsorption}

In order to investigate the spontaneity and thermodynamic properties of the adsorption process, the effect of the temperature on the adsorption process of $\mathrm{As}(\mathrm{V})$ was investigated by 
varying the temperature in the range of 298-318K. Specific thermodynamic parameters were calculated as follows: Gibbs free energy $\left(\mathrm{DG}^{0}\right)$, free enthalpy $\left(\mathrm{DH}^{0}\right)$ and free entropy $\left(\mathrm{DS}^{0}\right)$ with the following relations:

$$
\Delta G^{0}=-\mathrm{RT} \ln K_{d}
$$

where:

$$
K_{d}=\frac{\mathrm{C}_{\mathrm{Ae}}}{\mathrm{C}_{\mathrm{e}}}
$$

and:

$$
\log K_{d}=K_{d}=\frac{\Delta \mathrm{S}^{0}}{2.3 \mathrm{R}}-\frac{\Delta \mathrm{H}^{0}}{2.303 \mathrm{RT}}
$$

where $R$ is the universal gas constant $\left(8.314 \mathrm{~J} \mathrm{moL}^{-1} \mathrm{~K}\right), K_{\mathrm{d}}$ is the distribution coefficient,

$T$ is the absolute temperature $(\mathrm{K}), C_{\mathrm{Ae}}$ is the equilibrium concentration of $\mathrm{As}(\mathrm{V})$ on adsorbent $\left(\mu \mathrm{g} \mathrm{L}^{-1}\right)$ and $C_{\mathrm{e}}$ is the equilibrium concentration of $\mathrm{As}(\mathrm{V})$ in the solution $\left(\mu \mathrm{g} \mathrm{L}^{-1}\right)$. Thermodynamic parameters in the case of As (V) adsorption on the obtained material were determined from the slope of the straight line and ordered at the origin of the linear representation of $\ln K_{\mathrm{d}}$ as a function of $1 / T$ and the values of $\Delta \mathrm{G}^{\circ}, \Delta \mathrm{H}^{\circ}$ and $\Delta \mathrm{S}^{\circ}$ are shown in Fig. 8.

The correlation coefficient $R^{2}$ has a value equal to 0.9985 . The positive value of enthalpy $\Delta \mathrm{H}^{\circ}$ demonstrates that the energy necessary for the adsorption process is the energy used to put in contact $\mathrm{As}(\mathrm{V})$ ions with the surface of the adsorbent material. The negative value obtained for free Gibbs energy suggests that the adsorption process of As(V) on the functionalized material is a spontaneous and natural process. These values become more negative with the increase of temperature, which can be attributed to effective growth of the contact surface of the adsorbent material and the $\mathrm{As}(\mathrm{V})$ ions. The positive value of entropy $\left(\Delta \mathrm{S}^{\circ}\right)$ suggests that adsorption increases at the material/solution interface and the degree of particle clutter increases with increase in temperature, which can be attributed to some changes at the surface of the material. Thus, the adsorption of $\mathrm{As}(\mathrm{V})$ on the material surface is an endothermic and spontaneous process. Also, the value of activation energy has a value of 10.07 $\mathrm{kJ} \mathrm{mol}^{-1}$, suggesting that the adsorption of $\mathrm{As}(\mathrm{V})$ onto the studied material is a chemical adsorption.

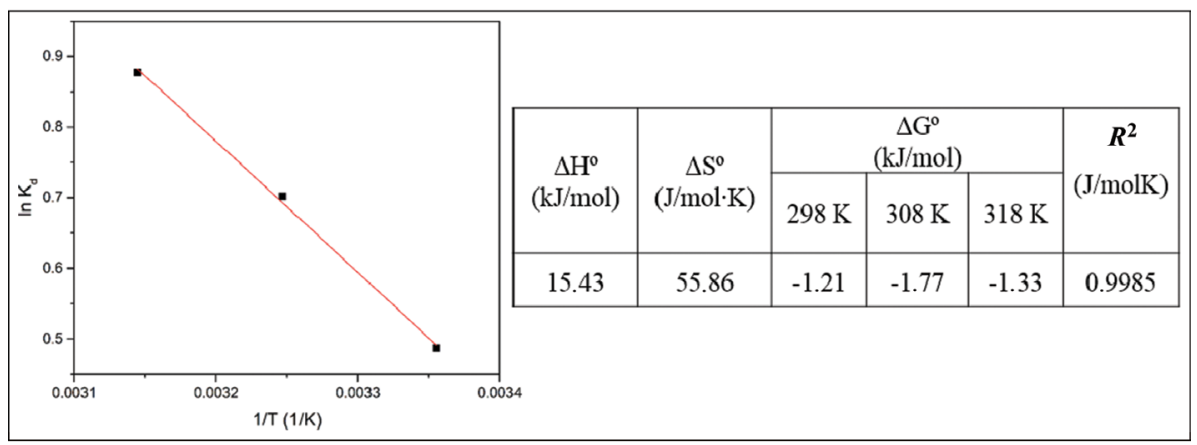

Figure 8: Arrhenius plot of $\mathrm{As}(\mathrm{V})$ adsorption onto adsorbent material. 


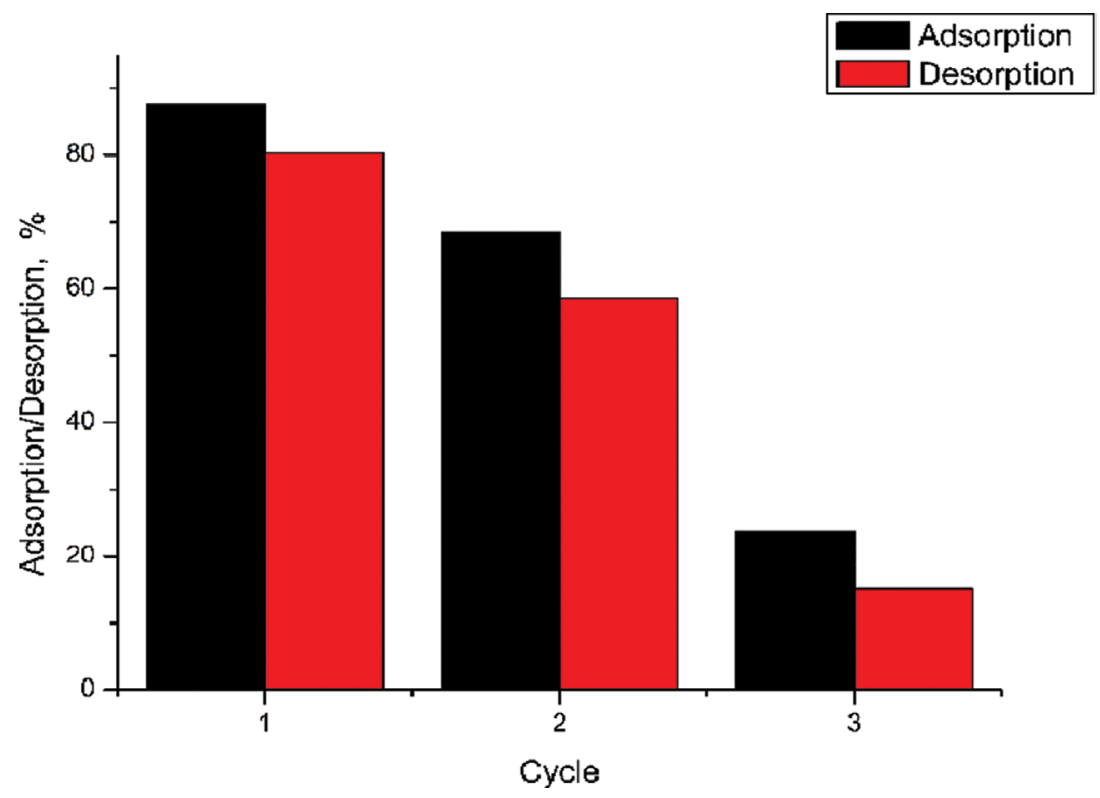

Figure 9: Adsorption-desorption cycles for $\mathrm{As}(\mathrm{V})$ uptake onto adsorbent material.

\subsubsection{Adsorption-desorption experiments}

Efficiency of the adsorbent material depends not only on his adsorption capacity but on his regenerative capacity and reuse as well. For this reason, in the present study, the possibility of reuse of the adsorbent material was investigated by establishing the adsorption/desorption cycle number (Fig. 9). Regeneration and reuse of the adsorbent material was performed by mixing $1 \mathrm{~g}$ material containing $\mathrm{As}(\mathrm{V})$ ions with $25 \mathrm{~mL} \mathrm{NaCl} 5 \%$. The mixture was shaken for $1 \mathrm{~h}$ at $200 \mathrm{rpm}$ at room temperature, filtered and afterwards the material was dried at room temperature. This cycle was repeated until the $\mathrm{As}(\mathrm{V})$ ions were irreversibly fixed onto the surface of the adsorbent material, establishing in this way the maximum number of usage cycles.

It was noticed that the material efficiency decreases gradually, from an adsorption/desorption cycle to another, until the material is exhausted. The studies have shown that the adsorbent material can be reused for three adsorption/desorption cycles.

\section{CONCLUSIONS}

The results reported in this study have shown that the new adsorbent material obtained from cellulose as solid support functionalized with crown ether di-benzo-18 crown-6 (DB18C6) and loaded with $\mathrm{Fe}$ (III) ions had as a result an increase of As(V) removal efficiency from water. The new material was characterized by X-ray EDX technique and FTIR spectroscopy to highlight the changes occurred on the surface of cellulose particles after crown ether functionalization and iron ion loading.

The maximum adsorption capacity of the new adsorbent material was $12.08 \mu \mathrm{g} \mathrm{As}(\mathrm{V}) / \mathrm{g}$ for an $\mathrm{As}(\mathrm{V})$ initial concentration of $60 \mathrm{mg} / \mathrm{L}$. Kinetic studies showed that the optimum contact time between $\mathrm{As}(\mathrm{V})$ solution and functionalized material was of $240 \mathrm{~min}$ and the 
optimum temperature was $298 \mathrm{~K}$. Experimental data were modelled using the pseudo-firstorder and the pseudo-second-order kinetic models. Based on the results, it was observed that the adsorption process is better described by the pseudo-second-order model.

Nonlinear regression analysis of the equilibrium data was performed using Langmuir, Freundlich and Sips isotherm models and the adsorption isotherm which best corresponds to the process is the Sips isotherm. The values of thermodynamic parameters were calculated and showed that the adsorption process was endothermic and spontaneous.

In order to study the efficiency of the new adsorbent material, adsorption-desorption experiments were carried out, and it was found that the material can be used for three cycles of adsorption/desorption

\section{ACKNOWLEDGEMENTS}

This work was supported by research grants PCD-TC-2017

\section{REFERENCES}

[1] Sharf Ilahi Siddiqui, S.A.C., Iron oxide and its modified forms as an adsorbent for arsenic removal: A comprehensive recent advancement. Process Safety and Environment Protection, 111, pp. 592-626, 2017.

[2] Kao, A.C., Chu, Y.J., Hsu, F.L. \& Liao, V.H.C., Removal of arsenic from groundwater by using a native isolated arsenite-oxidizing bacterium. Journal of Contaminant Hydrology, 155, pp. 1-8, 2013.

[3] Ng, J.C., Wang, J. \& Shraim, A., Global health problems caused by arsenic from natural sources. Chemosphere, 52, pp. 1353-1359, 2003.

[4] *** WHO, Arsenic in drinking water, World Health Organization, 2011 http://www. who.int/water_sanitation_health/dwq/chemicals/arsenic.pdf (accessed 30 November 2017).

[5] Ramesh, A., Hasegawa, H., Maki, T. \& Ueda, K., Adsorption of inorganic and organic arsenic from aqueous solutions by polymeric $\mathrm{Al} / \mathrm{Fe}$ modified montmorillonite. Separation and Purification Technology, 56, pp. 90-100,2007.

[6] Guo, H., Stuben, D. \& Berner, Z., Arsenic removal from water using natural iron mineral quartz sand columns. Science of the Total Environment, 377, pp. 142-151, 2007.

[7] Kundu, S. \& Gupta, A.K., Adsorptive removal of As(III) from aqueous solution using iron oxide coated cement (IOCC): Evaluation of kinetic, equilibrium and thermodynamic models. Separation and Purification Technology, 51, pp. 165-172, 2006.

[8] Borah, D., Satokawa, S., Kato, S. \& Kojima, T., Surface-modified carbon black for As(V) removal. Journal of Colloid and Interface Science, 319, pp. 53-62, 2008.

[9] Mohan D. \& P.J.C.U., Arsenic removal from water/wastewater using adsorbents-A critical review. Journal of Hazardous Materials, 142(1-2), pp. 1-53, 2007.

[10] Molinari R. \& A.P., Arsenic removal from water by coupling photocatalysis and complexation-ultrafiltration processes: A preliminary study. Water research, 109, pp. 327 336, 2017.

[11] Bora A.J., G.S., Baruah G. \& Dutta R.K., Utilization of co-existing iron in arsenic removal from groundwater by oxidation-coagulation at optimizated $\mathrm{pH}$. Journal of Environmental Chemical Engineering, 4, pp. 2683-2691, 2016.

[12] Banerji T. \& C.S., Arsenic removal from drinking water by electrocoagulation using iron electrodes - an understanding of the process parameters. Journal of Environmental Chemical Engineering, 4, pp. 3990-4000, 2016. 
[13] Ji J., Y.Y., Zenga Z., Wanga R., Zhenga X., Deng L. \& Li C., Preparation and arsenic adsorption assessment of PPESK ultrafiltration membranes with organic/inorganic additives. Applied Surface Science, 351, pp. 715-724, 2015.

[14] Zhao D., Y.Y., Wang C. \& Chen J.P., Zirconium/PVA modified flat-sheet PVDF membrane as a cost-effective adsorptive and filtration material: A case study on decontamination of organic arsenic in aqueous solutions. Journal of Colloid and Interface Science, 477, pp. 191-200, 2016.

[15] Salazar H., N.-P.J., Correia D.M., Cardoso V.F., Gonçalves R., Martins P.M., Ferdov S., Martins M.D., Botelho G. \& Lanceros-Méndez S., Selective separation of elements from complex solution matrix with molecular recognition plus macrocycles attached to a solid-phase: A review. Materials Chemistry and Physics, 183, pp. 430-434, 2016.

[16] Lee C.G., A.P.J.J., Nam A., Park S.J., Do T., Choi U.S. \& Lee S.H., Arsenic(V) removal using an amine-doped acrylic ion exchange fiber: Kinetic, equilibrium, and regeneration studies. Journal of Hazardous Materials, 123(1-3), pp. 223-229, 2017.

[17] Dhoble R. M. , M.P.R., Rayalu S. S., Bhole A.G. , Dhoble A. S. \& Dhoble S. R., Removal of arsenic(III) from water by magnetic binary oxide particles (MBOP): Experimental studies on fixed bed column. Journal of Hazardous Materials, Part B, pp. 469-478, 2017.

[18] Vithanage M., H.I., Joseph S., Bundschuh J., Bolan N., Ok Y.S., Kirkham M.B. \& Rinklebe J., Interaction of arsenic with biochar in soil and water: A critical review. Carbon, 113, pp. 219-230, 2017.

[19] Suda A. \& T.M., Functional effects of manganese and iron oxides on the dynamics of trace elements in soils with a special focus on arsenic and cadmium: A review. Geoderma, 270, pp. 68-75, 2016.

[20] Lata S. \& S.S.R., Removal of arsenic from water using nano adsorbents and challenges: A review. Journal of Environmental Management, 166, pp. 387-406 2016.

[21] Rahim M., H.M.R. \& Haris M., Application of biopolymer composites in arsenic removal from aqueous medium: A review. Journal of Radiation Research and Applied Sciences, 8, pp. 255-263, 2015.

[22] Roy P., M.N.K. \& Das K., Geochemistry and arsenic behaviour in groundwater resources of the Pannonian Basin (Hungary and Romania). Applied Geochemistry, 26(1), pp. 1-17, 2014.

[23] Abdel-Halim, E.S. \& Al-Deyab S.S., Removal of heavy metals from their aqueous solutions through adsorption onto natural polymers. Carbohydrate Polymers, 84(1), pp. 454-458, 2011.

[24] Huang, Z., et al., A novel biodegradable $\beta$-cyclodextrin-based hydrogel for the removal of heavy metal ions. Carbohydrate Polymers, 97(2), pp. 496-501, 2013.

[25] Podder, M.S. \& Majumder C.B., Bacteria immobilization on neem leaves/MnFe2O4 composite surface for removal of As(III) and As(V) from wastewater. Arabian Journal of Chemistry, 2015.

[26] Sheng, T., et al., Development, characterization and evaluation of iron-coated honeycomb briquette cinders for the removal of $\mathrm{As}(\mathrm{V})$ from aqueous solutions. Arabian Journal of Chemistry, 7(1), pp. 27-36, 2014.

[27] Lavoine, N., et al., Microfibrillated cellulose - Its barrier properties and applications in cellulosic materials: A review. Carbohydrate Polymers, 90(2), pp. 735-764, 2012.

[28] Šimkovic, I., Unexplored possibilities of all-polysaccharide composites. Carbohydrate Polymers, 95(2), pp. 697-715, 2013. 
[29] Schwaminger, S.P., et al., Nature of Interactions of Amino Acids with Bare Magnetite Nanoparticles. Journal of Physical Chemistry C, 119(40), pp. 23032-23041, 2015.

[30] Negrea, A., Popa, A., Ciopec, M., Lupa, L., Negrea, P., Davidescu, C. M., Motoc, M. \& Mînzatu, V., Phosphonium grafted styrene-diviniylbenzene resins impregnated with iron (III) and crown ethers for arsenic removal, Pure and Applied Chemistry, 86(11), pp. 1729-1740, 2014.

[31] Ciopec, M., Hulka, I., Duţeanu, N., Negrea, A., Grad, O., Negrea, P., Minzatu, V. \& Ardean, C., A new adsorbent for arsenic removal from water, WIT Transactions on Ecology and the Environment, 228, pp. 111-120, 2018.

[32] Hassan, H.S., Attallah, M.F. \& Yakout, S.M., Sorption characteristics of an economical sorbent material used for removal radioisotopes of cesium and europium, Journal of Radioanalytical and Nuclear Chemistry, 286, pp. 17-26, 2010.

[33] Gabor, A., Davidescu, C.M., Negrea, A., Ciopec, M., Muntean, C., Negrea, P., Ianasi, C. \& Butnariu, M., Magnesium silicate doped with environmentally friendly extractants used for rare earth elements adsorption, Desalinitation and water treatment, 63, pp. 124-134, 2017.

[34] El-Khaiary, M.I. \& Malash, G.F., Common data analysis errors in batch adsorption studies, Hydrometallurgy, 105, pp. 314-320, 2011.

[35] Foo, K.Y. \& Hameed, B.H., Insights into the modelling of adsorption isotherm systems, Chemical Engineering Journal. 156, 2-10, 2010.

[36] Alberti, G., Amendola, V., Pesavento, M. \& Biesuz, R., Beyond the synthesis of novel solid phases: review on modelling of sorption phenomena, Coordination Chemistry Reviews, 256, pp. 28-45, 2012.

[37] Langmuir, I., The adsorption of gases on plane surfaces of glass, mica and platinum, Journal of the American Chemical Society, 40(9), pp. 1361-1403, 1918.

[38] Freundlich, H.M.F., Uber die adsorption in losungen, Zeitschrift für Physikalische Chemie. 57, pp. 385-470, 1906.

[39] Sips, R., On the structure of a catalyst surface, The Journal of Physical Chemistry, 16, pp. 490-495, 1948.

[40] Negrea A., Ciopec M., Negrea P., Lupa L., Popa A., Davidescu C. M. \& Ilia G., Separation of $\mathrm{As}^{\mathrm{V}}$ from aqueous solutions using chelating polymers containing $\mathrm{Fe}^{\mathrm{III}}$ - loaded phosphorus groups, Open Chemistry, 13, pp. 105-112, 2015

[41] Gabor A., Davidescu C.M., Negrea A., Ciopec M. \& Lupa L., Behaviour of silica and florisil as solid supports in the removal process of As(V) from aqueous solutions, Journal of Analytical Methods in Chemistry, pp. 1-9, 2015. 